\title{
Víz, amiért érdemes útra kelni A táji környezet szerepe a vízparti utazás során
}

\author{
The role of the natural environment \\ in waterside travel destinations
}

\author{
SULYOK JUDIT
}

\author{
„Láttam festőknél és költőknél a szép s olykor \\ hamisítatlan természetet; de a legfóbb, végtelen, \\ utánozhatatlan természetet soha megfestve \\ nem láttam."
}

(Ugo Foscolo in Umberto Eco 2005: 284.)

KULCSSZAVAK: turizmus, turisztikai termék, motiváció, vízparti célállomás, imázs, földrajzi tér, természeti környezet, mentális térkép, márkaérték

ABSZTRAKT: A világ turizmusának jelentős részét adó vízparti úti célokat a keresleti és a kínálati trendek új kihívások elé állitják, ami a minőségi fejlesztések mellett az újrapozicionálást is szükségessé teszi. Az erősen vízhez kötődő tömegturizmus mellett az elmúlt években előtérbe kerültek a víztől független vonzerő- és létesítményfejlesztések, aminek során sokszor háttérbe szorult a táji környezet. A széles célcsoportok számára vonzó és elérhető vízpartok mára nem csupán a nyári utazás helyszínei, de az év többi időszakában is utazásra csábítanak. A tanulmány a magyarországi célállomások példáján keresztül keresi a válaszł arra, hogy a turizmusra predesztinált vízparti környezet a potenciális belföldi utazók tudatában hogyan jelenik meg. A szakirodalmi áttekintést követően lakossági kvantitatív vizsgálat segítségével mutatjuk be, hogy a táji környezet és annak egyes elemei hol helyezkednek el a vízpartokról alkotott képben, az utazási döntéshozatalban és a magyarországi célállomások egyedi jellemzői között. A kutatás eredményei szerint a vízpart által erőteljesen determinált természeti környezet a vízparton járt városlakók döntő többségének mentális térképén megjelenik. A megkérdezés rávilágított továbbá a belföldi utazás nyújtotta előnyökre, ami független a felkeresett célállomás környezetétöl, esetünkben a vízparttól. Területi szempontból vizsgálva elmondható, hogy minél közelebbi az úti cél, az utazók annál kisebb földrajzi egységben gondolkodnak. A víztől független vonzerők, tevékenységek közül a vízparton járt városlakók szerint az aktív pihenés önállóan is utazásra csábít, ezzel szemben a gasztronómia és a kulturális látnivalók jelenleg a hazai vízpartok felkeresésének élményét gazdagítják. Összefoglalóan elmondható, hogy a táji környezetre mint szervezőerőre építve kapcsolódhatnak be új célállomások a turizmusba, és az érett desztinációk is ennek figyelembevételével léphetnek a fenntartható és versenyképes jövő útjára.

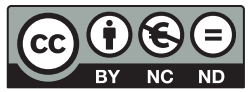


KEYWORDS: tourism, tourism product, motivation, waterside destination, Balaton, image, geographical area, natural environment, mental map, brand value

ABSTRACT: Waterside destinations make up the bulk of world tourism. Travellers of the post-mass-tourism era seek new and authentic experiences. This implies new challenges for waterside destinations, too. During the development of high quality services, new attractions and repositioning, the natural environment often takes second place. Today many waterside resorts are attractive for traveling not only during the summer season, motivating a wider range of travellers to visit them. Based on the Hungarian experience, the article focuses on the role of the natural environment in tourism to waterside places. Following an overview of the pertinent literature, the results of an empirical study conducted among potential Hungarian travelers (urban people with waterside holiday experience) are presented. The research includes the role of the natural environment in the image of a waterside holiday, in the decision-making process, and among the characteristics of Hungarian waterside destinations.

According to the study results, the natural environment is represented most strongly by the water-shore situation itself and plays an outstanding part in the image of a waterside holiday, independent of any socio-demographic factors analysed. So the natural environment at the waterside itself is an attraction for potential travelers. An interesting outcome of the research was that the advantages of a domestic trip ranked prominently when rating the characteristics and uniqueness of Hungarian waterside destinations. Besides the water, the flora and fauna, a nice panorama form important parts of the waterside natural enviroment on the mental map of potential travelers. The social-cultural aspect of a waterside destination deals only with the cotraveling family and friends, not with the host community. The 'place-specific' attractions are not dominant, and the general image of waterside destinations is strongly influenced by the image of Lake Balaton. The closer the destination is, the smaller the geographical area is (e.g. lake, city) on the mental map of urban people with waterside holiday experience. The research highlights sports, culture, gastronomy and wines, as well as health tourism among the attractions independent of the water attraction itself. Among them, sports can be a motivation for a waterside trip. This means that although the relaxation is still dominant at the watersides, the Hungarian destinations are more and more attractive during the low season as well. So tourism demand is shaped by touristic developments, and inversely, the demand trends call for new types of attractions, services, etc.

In conclusion, we point out that the awareness of the natural environment's role in waterside destinations can help to find the real values of those places. Mapping the watersides' characteristics in this study can be a success factor for a sustainable and competitive future in mature destinations, and can help develop new ones.

\section{Bevezetés}

Napjainkban a lakosság egyre nagyobb hányada vesz részt szabadidejében turisztikai célú utazáson. „Boldogító utazásaink” (Michalkó 2010) során nem csupán élményekkel leszünk gazdagabbak, de a környezetváltozás életminőségünket hosszabb távon is pozitívan befolyásolja. A természeti környezetnek (például a természet közelségének, a táj szépségének, harmóniájának, a környezet védelmének) a szerepe az élet számos területén előtérbe kerül (Bonaiuto et al. 2002), így a városi környezetből ki- 
szakadt utazók számára is kiemelt jelentőségű. A turizmus felől közelítve, az utazók számára növekvő szerepe van az egységes tájaknak, vidékeknek (Dávid, Tóth 2009).

Az 1980-as évek közepétől kezdődően az utazók a klasszikus tengerparti/vízparti üdüléssel szemben egyre inkább az új élmények sokaságát nyújtó utazásokat keresik (Yeoman 2007). Ugyancsak a vízpartok háttérbe szorulását eredményezheti a klímaváltozás, ami alapjaiban változtathatja meg a korábban vízre alapozó úti célok kínálatát. Ezzel szemben „reményre” adhat okot, hogy a jövőben kevesebb tó fogja kielégíteni a rekreációs igényeket (Baros et al. 2007).

A magyarországi vízparti úti célok széles csoportok számára elérhetők, az ország turizmusának kiemelt helyszínei, ezáltal jelentősen hozzájárulnak nem csupán a fogadóterület, de az egész ország gazdaságának teljesítményéhez is. A tömegturizmus leáldozásával, a rendszerváltozást követően a vízparti célállomások új kihívásokkal kerültek szembe, ami a minőségi fejlesztések mellett az újrapozicionálást is szükségessé tették. A tömegturizmus időszakában kiépült és fénykorukat élő desztinációk (például a Balaton) számára véleményem szerint nem lehet kérdés, hogy a jövőt az új, minőségi szolgáltatások jelenthetik (Povilanskas, Armaitiene 2011).

Az elmúlt évek fejlesztései során a természeti környezet sokszor háttérbe szorult (például all-inclusive szállodák). Ezért fontosnak tartom annak megismerését, hogy - konkrét úti céltól függetlenül - a potenciális kereslet számára a táji környezet mit jelent egy vízparti utazás során. A magyarországi vízpartok vizsgálatának turizmusföldrajzi megközelítése értékes információkkal szolgál az utazók attitűdjeiről, ezáltal segítve a turizmusban már részt vevő területek és a turizmusba a jövőben bekapcsolódó célállomások fejlődését.

Jelen cikk kiindulópontja, hogy a víz(part) azt a természeti környezetet adja, amelyben a potenciális utazók igényeik kielégítését keresik. A magyarországi vízparti célállomások területi szempontú megközelítését a potenciális utazók képzeletbeli térképén helyet kapó konkrét úti célok körének vizsgálata jelenti.

\section{Szakirodalmi kitekintés}

\section{Vízpartok a furizmus rendszerében}

A turizmus rendszerében a víz természeti vonzerő (Lengyel 1994, Michalkó 2007). A természeti vonzerők sorában több, a hazai vízpartokon is fellelhető tényező szerepel, így az éghajlat, a domborzat, a vulkanizmus, a növény- és állatvilág, a tájképi szépség vagy a talajadottságok (Michalkó 2007). A turisztikai desztináció „térbelileg lehatárolható földrajzi egységként” (Michalkó 2007:120.) értelmezhető, ami a vízpartokra különösen érvényes. A turisztikai miliő a látogatók 
szubjektív értékelésén túl összességében egy egységes képpé áll össze (Rátz, Michalkó 2008). A vízpart mint földrajzi tér a potenciális látogatók szemében egységesen jelenik meg, függetlenül attól, hogy közigazgatásilag egy egységet alkot-e (gondoljunk például a megyehatárokon átnyúló Balatonra és Tisza-tóra, vagy az országhatáron átnyúló Fertő tóra). A vízpartokon belül a tavak sajátos környezettel rendelkeznek, amelynek középpontját a táj adja (Rátz, Michalkó 2008). Ha vízparti utazásról van szó, a magyar lakosság elsősorban tavakra gondol (Rátz, Michalkó 2008, Magyar Turizmus Zrt. 2009/a, Magyar Turizmus Zrt. 2009/b). A turisztikai települések kategorizálására Michalkó (2007) a város, falu, illetve a vízpart és hegyvidék megkülönböztetését javasolja. „Az egyén különösen a térspecifikus turisztikai termékek (városi, falusi, hegyvidéki, vízparti turizmus, valamint az ökoturizmus) „fogyasztása” során találhat rá arra a helyre, amely elképzeléseiben, vágyaiban ideális (nem feltétlenül idilli) környezeteként él (Michalkó és tsai 2007:272.).

Más (például városi, falusi) terekhez hasonlóan a vízpartok is a társadalmi környezetbe illeszkedő fizikai térként (Farkas 2003) értelmezhetők: a táji környezeten túl az adott helyet meghatározza a társadalmi tér. Napjainkban egyre nagyobb szerepet kap a kultúrtáj, vagyis a turisztikai élményt adó úti cél elválaszthatatlan része a társadalom gazdasági, kulturális és esztétikai tevékenysége (Michalkó 2005). A magyarországi vízpartokon különösen meghatározó az emberi kéz nyoma, hiszen az elmúlt évszázadban az üdülési céllal második ingatlant vásárlók vélt és valós igényei alapjaiban alakították ezen területek (kiemelten a Balaton) mai arcát.

A vízpartok turisztikai jelentősége a kutatókat is megihleti. A nemzetközi tanulmányok legtöbbször a mediterrán tengerpartokat vizsgálva keresik a választ az aktuális kérdésekre, például arra, hogy az idojárás milyen hatással van az utazókra (Denstadli et al. 2011), vagy hogy a háttérterületek mily módon kapcsolhatók be a vízpartok turizmusába (Povilanskas, Armaitiene 2011). A víztől független turisztikai kínálat, ezen belül a wellness Finnország turizmusában kiemelkedő jelentőségü (például Tuohino, Kangas 2007). A turisztikai desztináció életciklusmodellje elsősorban a nemzetközi tanulmányokban kap helyet (például Agarwal 1997, Garay, Canoves 2010), Magyarországon az évszázados vendégfogadói hagyománnyal rendelkező Balaton esetében értelmezhető (Rátz 2007). Az éghajlatváltozás hazai célállomásokra gyakorolt hatását vizsgáló tanulmányt a koncepcionális megközelítéstől (Dávid, Tóth 2009) az utazói szokások vizsgálatáig (Rátz 2006) találunk. Ehhez hasonlóan kedvelt és aktuális téma az elmúlt években szezonhosszabbító céllal tett erőfeszítések, fejlesztések sikerességének vizsgálata (például Molnár 2007). A tanulmányok témájából jól látható, hogy a vízpartok nemzetközi és hazai szinten egyaránt hasonló problémákkal küzdenek, ezáltal a kutatások eredményei mind-mind értékes információkkal szolgálnak a vízparti turizmus mozaikszerűen összeálló képének megértéséhez. 
Magyarország turizmusa a kínálat térbeli eloszlása alapján turisztikai régiók és kiemelt üdülőkörzetek segítségével vizsgálható. A kilenc turisztikai régión belül kettő (a Balaton és a Tisza-tó) vonzerejét a vízpart jelenti. A kiemelt üdülőkörzetek esetében is jól megfigyelhetők a tájjal, földrajzi térrel kapcsolatos tényezők. A Balaton Kiemelt Üdülőkörzet (KÜ), a Dunakanyar KÜ, a Mátra-Bükk KÜ, a Mecsek és Villány KÜ, a Sopron-Kőszeghegyalja KÜ, a Tisza-tó KÜ és a Velencei-tó - Vértes KÜ önmagukban vonzó természeti környezettel várják a potenciális látogatókat. Míg a gazdaság területi szerveződését nagymértékben befolyásolja az infrastruktúra, az urbanizáció stb., addig a turizmus esetében a vonzerő, például a vízparti táj a fő kapocs a desztinációt adó települések között.

A természeti környezet értékei a konkrét magyarországi vízparti célállomásokat vizsgáló kutatásokban nyomon követhetők: például a Balaton-miliő szerves része a víz(felület), a hattyú, a kacsa, a dombok, a nádas, a szőlő és a gyümölcs (Rátz, Michalkó 2008); a Balaton mint úti cél képébe beletartozik a gyönyörű táj, a víz, a nagy tó (Magyar Turizmus Zrt. 2009/a); illetve a Tisza-tó értékei között kiemelt helyet kap a gazdag madár- és növényvilág (2009/b).

A hazai vízpartok jellemzően falusias-kisvárosias környezettel rendelkeznek, gazdasági erejük és érdekérvényesítő képességük korlátozott. Ennek ellenére a politikai elismertség jele, hogy Magyarországon az országos mellett a Balaton régiónak van területrendezési terve. Az érem másik oldala, hogy a vidékfejlesztésben oly fontos táj, a természeti erőforrások együttese sokszor csak a retorika szintjén jelentkezik, a konkrét programokban nem (Kulcsár 2012). A vízpartok életében a turizmus kiemelt szerepet kap (Baros et al. 2007), annak minden előnyével (például jövedelemtermelő erő, munkahelyek biztosítása) és hátrányával (például szezonalitás, a közüzemek túlterheltsége). Az ágazat munkahelyteremtő képessége különösen fontos, hiszen nagyszámú szakképzetlen munkaerőt képes felszívni. A turizmus a gazdaságilag kevésbé fejlett, ámde az utazók számára vonzó vízparttal rendelkező térségek számára is jó lehetőséget kínál a fejlődéshez (Dinya 2007, Galgóczy-Németh 2007). A gazdaságélénkítő szerep ugyanakkor sok esetben az egyedi pályázatok sikerétől függ, nem régiós szinten jelentkezik (Michalkó 2002).

\section{A vízpartok iránti turisztikai kereslet}

A vendégforgalom és a turizmusból származó bevételek alapján elmondható, hogy a világ turizmusának jelentős része a vízpartokhoz köthető (UNWTO 2011). Nincs ez másképp hazánkban sem: a vízpartok vezető helyet foglalnak el a belföldi és a beutazó vendégforgalomban egyaránt. A Magyarországon legalább egy éjszakát eltöltő külföldiek 12,9\%-a járt a Balatonnál (is), 0,9\%-a a Tisza-tónál (is) 2010-ben (forrás: KSH). A magyar lakosság legalább egy éjszakás tartózkodással járó belföldi utazásainak közel egyötöde a vízpartokra 
irányul, ezzel a második helyen áll a motivációk sorában a rokonok és barátok felkeresése után (Magyar Turizmus Zrt. 2010). A Központi Statisztikai Hivatal (KSH) által a magyar lakosság utazásait vizsgáló felmérések szerint a Balaton szerepe a legalább négyéjszakás utazások során kiemelkedő (KSH 2011), ami a klasszikus vízparti utazás dominanciájára hívja fel a figyelmet ${ }^{1}$.

A turisztikai szempontból legjelentősebb vízparti célállomások - a Balaton, a Tisza-tó, a Velencei-tó és a Fertő tó - vendégforgalmi adataiból jól látszik, hogy a kereskedelmi szálláshelyeken regisztrált vendégéjszakák többségét a belföldi utazók adják. A magyarországi tavak vonzereje - a Balaton kivételével - országosnak mondható. A Balaton esetében a beutazóforgalom többségét adó németek száma 2006 és 2010 között harmadával csökkent. A régió további fontos küldőpiacait - Ausztriát, Dániát és Hollandiát - is visszaesés jellemezte, amit részben ellensúlyoztak a közeli országokból (Csehországból, Szlovákiából, Szlovéniából és Ukrajnából) nagyobb számban érkezők (1. táblázat).

1. táblázat: A magyarországi vízpartok vendégforgalma

(a vendégéjszakák száma a kereskedelmi szálláshelyeken)

Number of guest nights at commercial accommodation in the main Hungarian waterside destinations

\begin{tabular}{llrrrrr}
\hline & & \multicolumn{1}{c}{2006} & \multicolumn{1}{c}{2007} & \multicolumn{1}{c}{2008} & \multicolumn{1}{c}{2009} & \multicolumn{1}{c}{2010} \\
\hline Balaton & belföldi & 2366744 & 2568001 & 2616246 & 2605285 & 2617888 \\
& külföldi & 2060234 & 2021108 & 1918941 & 1660708 & 1613778 \\
& Összesen & 4426978 & 4589109 & 4535187 & 4265993 & 4231666 \\
\hline Tisza-tó & belföldi & 168505 & 183994 & 210994 & 196563 & 182688 \\
& külföldi & 65134 & 71062 & 79315 & 70136 & 63890 \\
& Összesen & 233639 & 255056 & 290309 & 266699 & 246578 \\
\hline Velencei-tó & belföldi & 130000 & 138000 & 128171 & 163072 & 203774 \\
& külföldi & 42000 & 35000 & 29495 & 31362 & 36918 \\
& Összesen & 172000 & 173000 & 157666 & 194434 & 240692 \\
\hline Fertő tó & belföldi & 399798 & 383702 & 388868 & 367355 & 416170 \\
(Sopron-Fertődi & külföldi & 146124 & 140020 & 148971 & 149287 & 163359 \\
kistérség) & Összesen & 545922 & 523722 & 537839 & 516642 & 579529 \\
\hline
\end{tabular}

Forrás: KSH.

Míg a tömegturizmus időszakában az utazói réteg homogénebb volt, ma a vízparti célállomásokat felkeresók motivációi sokrétüek. A vízpartokhoz, ezen belül kiemelten a tengerpartokhoz köthet” úgynevezett „ $4 \mathrm{~S}^{\prime}$ motiváció kisebb jelentőséggel a tópartokon is jelen van. A magyarországi célterületek vizsgálatakor a passzív pihenés ${ }^{2}$ a tengerpart hiánya miatt különösen releváns. Az elmúlt években a vízpartokon végbement, a szezon meghosszabbítására és új szegmensek megnyerésére irányuló fejlesztések következtében a látogatók ma már nem csupán a passzív pihenést keresik. Az erősen fragmentált kereslet sikeres megszólítása a desztinációk számára komoly kihívást jelent, mert sok esetben a nyári föszezon és az ezen túli időszak kínálata markánsan elkülönül egymástól. Az erős időbeli koncentrációt mutató úti célok, a vízpartok és a síparadicsomok számára éppen ezért fontos, hogy a szezonális vonzerök mellett legyen egy közös alap (Moilanen, Rainisto 2009), ami véleményem szerint maga a természeti környezet lehet. 


\section{Módszertan}

A magyar lakosság vízparti utazással szembeni attitűdjeit vizsgáló kvantitatív kutatás az MTA Földrajztudományi Kutatóintézet és a Kodolányi János Főiskola együttműködésének keretében zajlott, az Országos Tudományos Kutatási Alapprogramok (OTKA) támogatásával. ${ }^{3}$

A kutatás fő célja volt, hogy konkrét célállomástól függetlenül vizsgálja a vízpart által erősen determinált természeti környezet szerepét az utazások során. A turisztikai desztinációk természeti környezet (például vízpart, hegyvidék, falu, város) szerinti vizsgálatát indokolja, hogy a hazai vízpartokon is elindultak a víztől független vonzerőfejlesztések.

A kutatás a következő témaköröket ölelte fel ${ }^{4}$ :

- a vízparti utazásról alkotott kép;

- a magyarországi vízparti úti célok jellemzői és ezek fontossága az utazási döntéshozatalban;

- a magyarországi vízparti úti célok egyedisége;

- a magyarországi vízpartok látogatottsága.

A belföldi lakosság megkérdezését indokolja a belföldi vendégforgalom dominanciája a hazai vízpartokon. Az adatfelvételre 2009 nyarán került sor, 668 értékelhető kérdőív érkezett be. A megkérdezés körülményei a megkérdezettek kor és nem szerinti összetételét engedték figyelembe venni, amelynek kialakításához a magyar lakosság utazási szokásait vizsgáló, reprezentatív mintán történő felmérések szolgáltak alapul.

A felmérésbe bevont minta a magyar lakossággal nem és életkor szerint mutat hasonló megoszlást. A megkérdezettek többsége városban él, és járt már magyarországi vízparton szabadidős céllal. A vizsgálat eredményei a vízparti utazási tapasztalattal rendelkező városi lakosság preferenciáit tükrözik.

A válaszadók döntő többsége $(93,9 \%)$ részt vett szabadidős célú utazáson a megelőző három évben (2006-2008 között), vagyis az eredmények az aktív utazókra vonatkoznak (az utazók 57,6\%-a belföldön és külföldön, 36,9\%-a csak belföldön, 5,5\%-a csak külföldön járt). A válaszadók döntő többsége, tízből kilencen jártak a megkérdezést megelőző három évben magyarországi vízparton. ${ }^{5} \mathrm{~A}$ belföldön és külföldön is utazók körében a vízpartok még népszerübbek: a válaszadók 98\%-a járt vízparton (is). Az egyes vízpartok közül a tavak jelentősége kiemelkedő. A turisztikai szempontból két legjelentősebb tó felkeresése a következőképpen alakult: a válaszadók 59,0\%-a csak a Balatont ${ }^{6}, 4,6 \%$-a csak a Tisza-tavat választotta, míg a mindkét tópartot felkeresők aránya $26,8 \%$ volt a vizsgált mintában. 


\section{Eredmények}

\section{A vízparti utazás imázsa a vizsgált mintában}

A vízparti utazásról alkotott képet a kutatás nyílt kérdéssel vizsgálta. A megkérdezettek sorrendben öt asszociációt említhettek, amelyek közül az első helyen megnevezett tényezőket külön is elemeztem. A vízparti úti célokról szinte mindenkinek (658 fó) eszébe jutott valami. A vízparti utazások sokszínűségét jelzi a több mint 80 féle dolog.

A vízparti utazás hallatán a vizsgálatba bevontak többségének a passzív pihenés és a nyári időszakhoz szorosan kapcsolódó napsütés, fürdés jut az eszébe. A vízparton járt városlakók számára szorosan összefonódik a vízpart és a klasszikus nyári üdülés. A vízparti utazás része a gasztronómia, az aktív pihenés és sportolás, a kulturális programok és a szórakozási lehetőségek. A személyes tapasztalatok a konkrétan említett célállomásokban tükröződnek vissza. A megkérdezettek körében a vízpart emberi arcát az együtt utazók (család és a barátok) alkotják. A turizmusba bekapcsolódni kívánó vízpartokon ma már nem elegendő a nyári fürdőzés lehetőségének megteremtése, hanem a helyi adottságokhoz és az uta-

1. ábra: A vízparti utazással társított tényezők (szúkített kategóriák, 1\% feletti említések) Associations of the waterside holiday (reduced categories, $1 \%+$ reference)

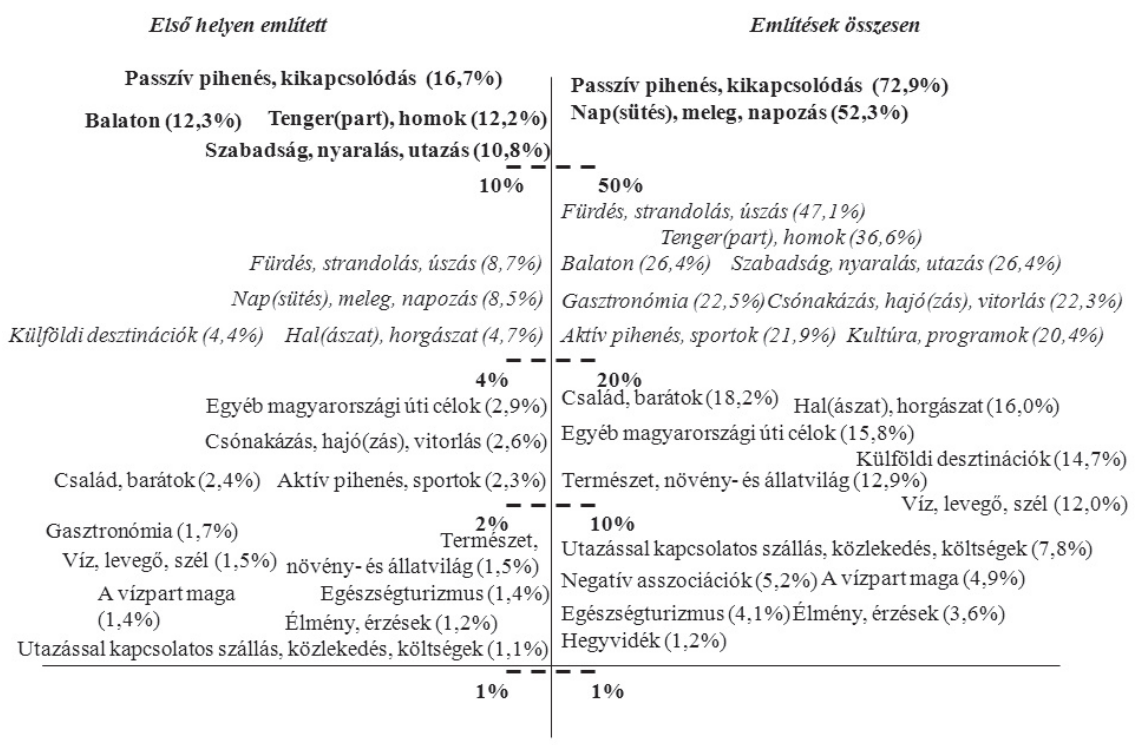

Forrás: saját kutatás, $n=658$ fő. 
zói igényekhez igazodó széles körü turisztikai kínálat kialakítása szükséges, aminek alapja a természeti környezet.

A vízparti utazásról alkotott, egy színes mozaikként értelmezhetó képet a megkérdezettek tudatában a vízhez közvetlenül vagy közvetve kötődö társitások, az utazáshoz kapcsolódó képzetek és az egyéni szubjektivitás, a saját utazási tapasztalatok alkotják (1. ábra).

\section{A víz és a táji környezet helye a vízparti utazásról alkotott képben}

A víz és a táji környezet a megkérdezettek többsége (84\%) számára része az utazásnak. A „vízpartiság” a társítások között számos ponton megfigyelheto”. Szükebb értelemben véve, a természeti környezet része az „üde környezet”, a „szép táj” mellett a szép kilátás, a növény- és az állatvilág. Az említett növények és állatok között egyértelműen a vízhez kötődők szerepelnek a megkérdezettek tudatában (például nádas, kacsa, sirály).

A fürdőzés vezető szerepe a tevékenységek között komoly kihívás elé állítja a néhány hónapos fürdőzési lehetőséget kínáló hazai vízpartokat. A vizsgált mintában markánsan jelennek meg a vízhez kapcsolódó egyéb tevékenységek: a csónakázás, hajókázás és a horgászat, amelyek a fürdőzési szezonon kívül is végezhetők.

Tágabb értelemben véve, a vízparti táj élményével kapcsolatban álló imázselem a napsütés, a tenger és a homok, a víz, a levegő és a szél.

A vizsgálatba bevont potenciális utazók feltételezett heterogenitásának ellenére az utazási élmény legtöbbször ,ingyenes” részét jelento” vizparti táj a legtöbbek számára az imázs szerves része. A természeti környezet vonzereje alapozhatja meg a desztinációk turisztikai szezontól és utazói szegmensektöl független márkaértékeit, amelyekre az egyes célállomások saját, egyedi turisztikai kínálatukat épithetik.

\section{A víztól független imázselemek szerepe}

A természeti környezet a vízpartokon korlátozottan megváltoztatható erőforrás. A természeti adottságokra alapozhat az egyes úti célok turisztikai kínálata. A szezonhosszabbító törekvéseknek köszönhetően az elmúlt években középpontba került a víztől független turisztikai termékek, tevékenységek fejlesztése. Néhány év tapasztalata, eredményei után joggal merül fel a kérdés, hogy önmagukban ezek a tevékenységek csábítanak-e utazásra? Vagy csak az utazás kellékei, és rossz időjárás esetére kínálnak alternatívát a fürdőzésre?

A vizsgált mintában - az 1\% feletti spontán társítások alapján - 1) az aktív pihenés és sportolási lehetőségek, 2) a gasztronómia (ideértve a borturizmust) 3) a kulturális turizmus és 4) az egészségturizmus jelentek meg. A vízparton járt városlakók körében az aktív turisztikai szolgáltatások kapcsolódnak leginkább a vízparti utazáshoz. A sporttevékenységek szerves része a természeti környezet, 
például a Balaton körüli kerékpárúthoz hozzátartozik a gyönyörü panoráma. Az elmúlt években dinamikus fejlődésnek indult vitorlázás önmagában nem jelent meg számottevő mértékben a megkérdezettek tudatában, ez a lehetőség a nagyközönség nagy részének mind a mai napig nem elérhető. A gasztronómia elsősorban az utazás során történő étel- és italfogyasztást jelenti. A kulturális látnivalók felkeresése, a programok legtöbbször rossz időjárás esetén kerülnek előtérbe. Ennek hátterében minden bizonnyal az is szerepet játszik, hogy a helyi tradíciók és az épített örökség ellenére a magyar tájak ismerős kulturális közeget kínálnak a belföldi utazók számára. Az egészségturizmus szűk célcsoportok számára vonzó.

A víztöl független turisztikai termékek megjelenése a társitásokban arra utal, hogy 1) a vízpartok vendégköre egyre sokszinübb, és 2) a fejlesztéseknek köszönhetöen a vízpartok nem csupán nyáron vonzók. Az aktív pihenés és a sportolási lehetőségek a kutatás eredményei szerint önállóan is utazásra csábitóak. A gasztronómia és a kulturális látnivalók, programok az utazási élményt gazdagitják. A vízparton járt városlakók szerint az egészségturisztikai szolgáltatások az utazás alatt végzett tevékenységként is csak szük célcsoportok számára vonzók.

\section{Vizparti célállomások a megkérdezettek mentális térképén}

A vízparti utazás a turisztikai kínálat jellege mellett desztinációk irányába bontható tovább. A vízparti utazással társított célállomások ismerete segít feltérképezni a potenciális versenytársak körét. Ezen túlmenően a fogadóterületek turisztikai hatásköreinek, feladatainak meghatározását támogatja, ami Magyarországon különösen aktuális a turisztikai desztinációk most formálódó menedzsmentszervezetei (TDM) miatt.

A vizsgálat eredményei szerint a megkérdezettek tudatában a Balaton és a tenger(part) állnak a legelőkelőbb helyeken. A Balaton előkelő pozíciója felveti azt a kérdést, hogy a legnagyobb hazai tavunkról alkotott kép milyen mértékben befolyásolja a vízparti utazás imázsát általánosságban. A megkérdezett potenciális utazók „térképén” a hazai vízpartok megelőzik a külföldi úti célokat. Ennek hátterében szerepet játszik a magyarországi vízpartok gazdag kínálata és az, hogy a vízparti utazás a nagyközönség többsége számára vonzó és elérhető. Konkrét külföldi desztinációt kevesen említettek a vizsgált mintában, akik mégis, azoknál Horvátország jelent meg önállóan.

A hazai vízparti úti célok között egyértelműen a Balaton áll az első helyen, ezt a Velencei-tó (21 említés), a Tisza (28 említés) és a Duna (19 említés) ${ }^{7}$ követi. Ha vízpart, akkor a válaszadók - a tengert követően - elsősorban tavakra gondolnak, és nem folyókra. Konkrét település a Balaton és a Tisza-tó esetében került a képzeletbeli térképre a vizsgált mintában. A balatoniak közül Alsóörs, Badacsony, Balatonakarattya, Balatonmáriafürdő, Siófok, Szigliget és Tihany; a Tisza-tónál Abádszalók és Tiszafüred szerepeltek. 
A vízparti célállomásokat területi szempontból vizsgálva elmondható, hogy minél közelebb fekszik a küldő- és a fogadóterület, annál kisebb földrajzi egységben gondolkodnak az utazók. A kutatásba bevont vízparton járó városlakók belföld esetében tavakra, ezen belül településekre, külföld esetében országokra asszociálnak. Az említett desztinációk kis száma arra utal, hogy kevés vízpart rendelkezik országos vonzerővel. Az említett települések kis száma felhívja a figyelmet arra, hogy a hazai vízpartokon nem csupán a part menti és nem part menti területek között, de a part mentén is jelentős különbségek tapasztalhatók. A vizsgálat következtetései szerint a hazai vízpartokon formálódó TDM-ek a belföldi utazóközönséget megcélzó tevékenységek ellátására hivatottak. Emellett a magyarországi vízparti utazást egy egységként lehet a nemzetközi piacokon megismertetni.

\section{A magyarországi vízpartokról alkotott kép}

A vízparti utazásról alkotott kép „feltérképezését” szolgálta a magyarországi vízpartok jellemzőinek megismerése. A vizsgált 23 tényezőt a válaszadók ötfokú skálán értékelték, ahol 1=egyáltalán nem jellemző és $5=$ nagyon jellemző.

A kutatásba bevont potenciális utazók szerint a magyarországi vízpartok legfőbb jellemzője:

- a pihenésre alkalmas környezet $(3,10)$, a természeti adottságok (a természeti értékek gazdagsága $(2,88)$, a vonzó tájképi környezet $(2,84)$, a nyugalom $(2,79)$, a kedvező időjárási feltételek $(2,78)$ és

- az utazáshoz szükséges alap-infrastruktúra (a színvonalas szálláshelyek $(2,81)$, a sokféle látnivaló $(2,78)$, a színvonalas vendéglők $(2,75)$, a jó megközelíthetőség $(2,64)$ és a vásárlási lehetőségek $(2,60))$.

A víztől független vonzerők, a kulturális programok $(2,52)$ és a sportolási lehetőségek $(2,41)$ a középmezőnyben helyezkednek el. A magyarországi vízpartokat a felmérésbe bevontak szerint legkevésbé az érintetlen természet $(2,02)$, a megfelelő parkolási feltételek $(2,07)$ és a divatosság $(2,09)$ jellemzi. A legegységesebben értékelt a pihenésre alkalmas környezet (szórás 0,68). Az egyes tényezők közül a legnagyobb (1 feletti) szórást a szórakozási lehetőségek, a tömegturizmus, a sportolási lehetőségek, az egyedi környezet, a jó közbiztonság, a jó ismerkedési lehetőségek és az érintetlen természet mutatják.

A kérdőívben szereplő 23 tényezőt faktorelemzés (maximum-likelihood elemzés varimax rotációs eljárással) is vizsgálta. 12 tényező négy faktorba rendezhető. A KMO értéke 0,69, a Khí-négyzet értéke 1448,634, a négy faktor így a változók 61\%-át magyarázza. A faktorok alapján - a vízpartokról alkotott képpel összhangban - elmondható, hogy a vízpartoknak van egy a természeti környezettel kapcsolatos észlelési szintje:

- 1. számú faktor („belföldi”): kedvező ár/érték-arány, jó közbiztonság, kedvező időjárási feltételek.

- 2. számú faktor (,infrastruktúra”): színvonalas szálláshelyek, színvonalas vendéglők. 
- 3. számú faktor („,pezsgő élet”): szórakozsi lehetőségek, éjszakai élet, jó ismerkedési, kapcsolatteremtési lehetőségek, tömegturizmus ${ }^{8}$, vásárlási lehetőségek.

- 4. számú faktor („vízparti táj”): természeti értékek gazdagsága, kulturális programok tárháza, egyedi, mással össze nem hasonlítható környezet.

A vizsgált mintában a magyarországi vízpartok jellemzői között elkülönülnek a vízparti tájjal kapcsolatos tényezók. A természeti környezettel párhuzamosan megjelenö észlelési szint a belföldi utazás nyújtotta elönyök, a turisztikai infrastruktúra és a pezsgö élet. A viztöl független jellemzők alacsonyabb értéke és a magas szórást mutató tényezók a potenciális kereslet fragmentáltságára engednek következtetni.

\section{A táji környezet szerepe az utazási döntéshozatalban}

A hazai vízpartok jellemzőinek feltérképezése mellett fontos az egyes tényezők (23 tényező értékelése ötfokú skálán, ahol 1=egyáltalán nem fontos és $5=$ =nagyon fontos) döntéshozatalban játszott szerepének megismerése. Az utazási döntéshozatalban az úti cél egy tényező a sok között (Zalatan 1996), úgymint például a motiváció, a szabadidő, a jövedelem, a családi állapot, az egyéni értékrend vagy az életvitel. Az utazási döntés meghozatalakor a vizsgált mintában a legfontosabb szempont

- a pihenésre alkalmas környezet $(4,50)$, a kedvező ár/érték-arány $(4,50)$, a jó közbiztonság $(4,47)$, továbbá

- a nyugalom (4,38), a kedvező időjárási feltételek $(4,36)$, a jó megközelíthetőség $(4,19)$, a színvonalas vendéglők $(4,10)$, a színvonalas szálláshelyek $(4,08)$, a sokféle látnivaló $(4,07)$ és a vonzó tájképi környezet $(4,06)$.

A vízparti utazásról való döntést legkevésbé a desztináció divatossága $(2,76)$ és a tömegturizmus $(2,48)$ alakítják a vizsgálatba bevontak körében. A legegységesebbek a válaszadók a pihenésre alkalmas környezet (szórás 0,73$)$ tekintetében. Alacsony ( 0,9 alatti) szórást mutat még a megközelíthetőség $(0,87)$, a kedvező ár/érték-arány $(0,82)$ és a jó közbiztonság $(0,86)$, amelyek a belföldi utazás előnyeire utalhatnak a vizsgált mintában. Ezzel szemben a legnagyobb (1,2 feletti) szórás a parkolási, a sportolási, a szórakozási, a kapcsolatteremtési lehetőségek és a divatosság kapcsán jelentkezik.

A kérdőívben szereplő 23 tényező fontosságát az utazási döntéshozatalban faktorelemzés (maximum-likelihood elemzés varimax rotációs eljárással) is vizsgálta. Ennek eredményeként 11 tényező rendezhető négy faktorba. A KMO értéke 0,666, a Khí-négyzet értéke 1297,415, a négy faktor így a változók 63\%-át magyarázza. Az egyes faktorok:

- 1. számú faktor (vízparti táj): egyedi, mással össze nem hasonlítható környezet, vonzó tájképi környezet, érintetlen természet.

- 2. számú faktor: színvonalas vendéglők, színvonalas szálláshelyek, széles körü információ.

- 3. számú faktor: kedvező ár/érték-arány, kedvező időjárási feltételek, jó közbiztonság. 
- 4. számú faktor: szórakozási lehetőségek, éjszakai élet, jó ismerkedési, kapcsolatteremtési lehetőségek.

A döntéshozatal során hasonló észlelési szintek különülnek el, így a vízparti tájjal kapcsolatos elemek egy faktorba rendeződtek a vizsgált mintában. A megkérdezett potenciális utazók számára a célállomás földrajzi környezete meghatározó, egységként érzékelt része a döntéshozatalnak.

A magyarországi vízpartok jellemzőinek és a döntéshozatalban betöltött szerepüknek együttes vizsgálata alapján elmondható, hogy a megkérdezettek számára a vízparti tájjal kapcsolatos tényezők a hazai úti célok jellemző vonásai, és a döntéshozatal során fontos tényezők. Emellett az elsődleges turisztikai szuprastruktúra (szálláshelyek és vendéglátóhely) szerepel itt, valamint a belföldi úti célok előnyeként számon tartott jó megközelíthetőség és a vízparti utazások elengedhetetlen „kelléke”, a kedvező időjárás. Az érintetlen természet kevésbé jellemző és fontos a válaszadók körében, ami a magyarországi vízpartok kiépítettségét, a turizmusba való aktív bekapcsolódását jelzi. A közbiztonság és az ár/érték-arány voltak azok a tényezők, amelyek a felkeresett célállomás táji környezetétől (esetünkben a vízparttól) függetlenül előtérbe kerültek (2. ábra).

2. ábra: Magyarországi vízparti úti célok jellemzői és azok fontossága az utazási döntéshozatallban

Characteristics of the Hungarian waterside destinations and their importance in the travel decision

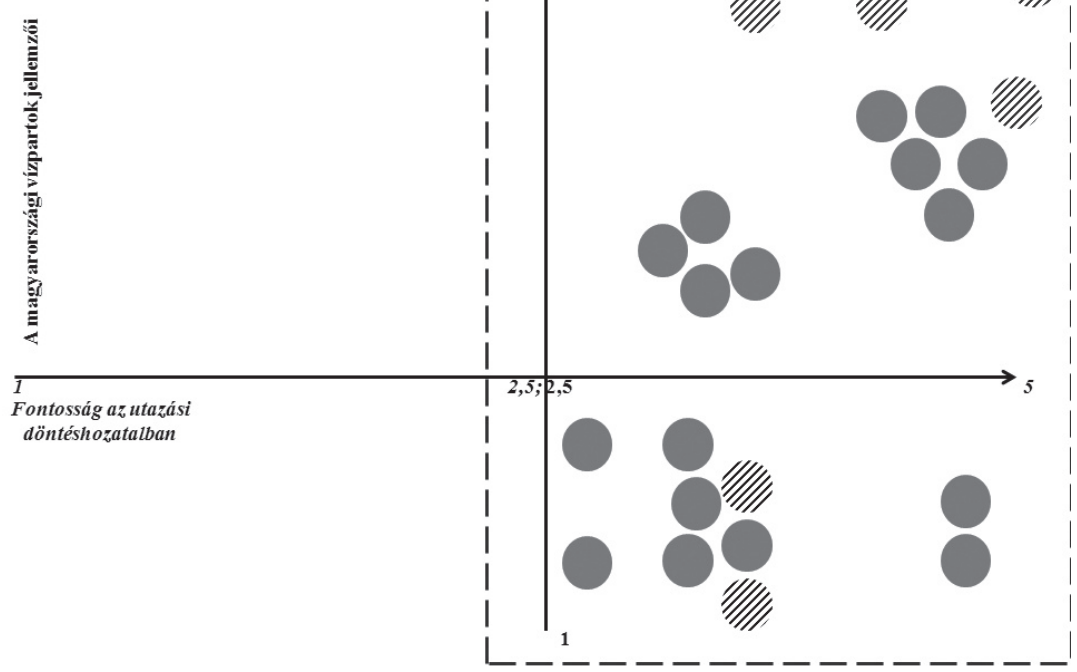


A keretezett rész nagyítva:

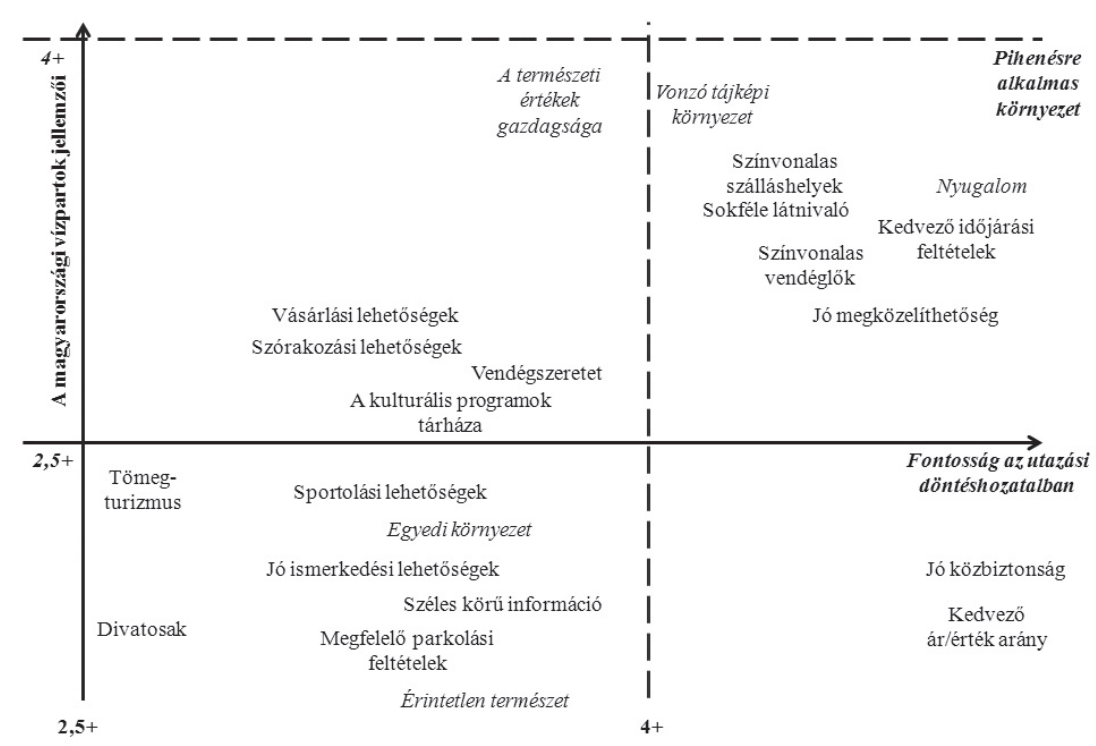

Megjegyzés: a dőlt betúvel kiemeltek a természeti környezettel kapcsolatos tényezök. Forrás: saját kutatás.

\section{A magyarországi vízparti úti célok egyedisége}

A vízparti utazás és a magyarországi vízpartok értékelését a hazai célállomások nemzetközi összehasonlításban értelmezett egyedi vonásainak feltérképezése teszi teljessé. A hazai vízpartok egyediségét nyitott kérdés vizsgálta: a 668 fó közül 621-en fogalmazták meg gondolataikat, 23 válaszadó nem tartja egyedinek a hazai desztinációkat.

A táji környezetet és a vele szoros kapcsolatban álló növény- és állatvilágot találjuk az első helyen: a vízpartok már önmagukban egyedi élményt nyújtanak a mindennapokból kiszakadó utazóknak. A közeliség és a hazai utazás biztonsága sokak tudatában megkülönbözteti a hazai célállomásokat a külfölditől, aminek ellenpólusát néhány válaszadó számára az ismert környezettel párosuló „unalmasság”, a teljes kikapcsolódás hiánya adja. A belföldi utazás presztízsét emeli ugyanakkor, hogy sokan fontosnak tartják a hazai értékek megismerését. A „megfoghatatlan” emlékek, a hangulatot tükröző egyediségek a harmadik helyen következnek, ami alátámasztja az egyéni szubjektivitás fontosságát és az utazási élmény egyediségét (más és más élmény ér bennünket, ha ugyanazt az úti célt többször keressük fel).

A vízhez közvetlenül nem kötődő turisztikai termékek közül legtöbben a kultúrát és az egészségturizmust említették, megelőzve a gasztronómiát, az aktív 
pihenést és a borturizmust ${ }^{9}$. A vizsgált mintában a célállomás emberi arca (vendégszeretet képében) itt megjelenik. Az egyediség tekintetében jelentős véleménykülönbségek figyelhetők meg a felmérésbe bevontak körében. Szerintük a magyarországi vízparti úti célok

- inkább olcsóbbak, mint drágábbak a külföldi úti célokkal összehasonlítva;

- inkább nyugodtak és pihenésre alkalmasak, mint zsúfoltak; és

- többek számára inkább a biztonságot adják, mintsem az ezzel párhuzamba állítható „unalmasságot” jelentik.

A kutatás eredményei szerint a megkérdezettek tudatában a magyarországi vízpartok megkülönböztetó jegyei között elötérben állnak a vízparti tájjal és a belföldi utazás előnyeivel kapcsolatos tényezők. A vizsgált mintában a magyarországi vízpartokat körülölelö táj önmagában egyedinek tekinthető. Erre épülnek a szükebb célcsoportokat megszólitó turisztikai termékek, tevékenységek, igy a kulturális látnivalók, az egészségturisztikai szolgáltatások, a bor és gasztronómia, a horgászat, valamint az aktív pihenés (2. táblázat).

2. táblázat: A magyarországi vízparti úti célok egyedisége Uniqueness of the Hungarian waterside destinations

\begin{tabular}{lr}
\hline Megnevezés & Említések száma \\
\hline Természeti értékek, állat- és növényvilág, kellemes klíma & 122 \\
Közeli, jól megközelíthető & 113 \\
"Egyedi”, konkrét helyek, emlékek, hangulat, nosztalgia & 79 \\
A „hazai” biztonsága (pl. nyelv), a belföldi értékek megismerése & 78 \\
Olcsóbb & 66 \\
Az édesvíz elönyei a sós tengerrel szemben (pl. sekély, családosok- & 51 \\
nak alkalmasabb), füves strandok & 42 \\
Kulturális látnivalók, programok & 42 \\
Nyugodt, nem zsúfolt, pihenésre alkalmas & 41 \\
Gyógyvizek, egészségturizmus & 35 \\
Alacsony színvonal, a külföldinél alacsonyabb színvonal & 31 \\
Vendégszeretet, barátságos, családias & 30 \\
Gasztronómia & 29 \\
Koszos, rendezetlen, elhanyagolt & 16 \\
Drága, a külföldinél drágább & 15 \\
Horgászati lehetöségek & 15 \\
Sokféle lehetöség, szolgáltatások (mindenki megtalálja a magának & 14 \\
legmegfelelöbbet) & 11 \\
Nem egyedi, a külföld-belföld ugyanolyan & 9 \\
Nem elég „izgalmas”, nem kapcsol ki eléggé & 9 \\
Aktív pihenés, sportolási lehetőségek & 7 \\
Nem összehasonlítható a tenger a tavakkal & 7 \\
Borturizmus & 2 \\
Zsúfolt, tömeg, sok turista & \\
Szúnyogok &
\end{tabular}

Forrás: saját kutatás. 


\section{Következtetések}

A kutatás eredményei igazolnak több turizmuselméleti tételt. Eszerint a vízpartok a turizmusban kiemelkedő szerepet töltenek be, széles célcsoportok számára vonzók és elérhetők. A vízpartok turizmusa döntően a nyári időszakhoz köthető, az utazási élmény szerves része a kedvező időjárás. A vizsgálatba bevont potenciális utazók tudatában a vízparti desztináció egy egységként jelenik meg, az úti célok önmagukban is vonzóak.

A víz által erőteljesen determinált természeti környezet, aminek része a víz maga és a hozzá szorosan kapcsolódó növény- és állatvilág, továbbá a szép kilátás, a vízparti utazásról általánosságban alkotott képben számos ponton megjelenik, az imázs szerves része. A vízre és a körülölelő tájra a megkérdezettek a magyarországi célállomások esetében egységként tekintenek. A természeti környezettel kapcsolatos tényezők az utazási döntéshozatal során egy faktorba rendeződnek. A természeti értékek a hazai vízpartokat nemzetközi összehasonlításban is megkülönböztetik potenciális versenytársaiktól.

A táj emberi arcát a vízparti utazásról alkotott képben az együttutazók (család, barátok) alkotják a vizsgált mintában. A fogadóterület lakossága, a vendégszeretet a magyarországi desztinációk egyedi jellemzői között kapott helyet.

A víztől független vonzerők, amelyek az elmúlt években előtérbe kerültek szezonhosszabbító célú turisztikai fejlesztések kapcsán, részben önállóan is utazásra csábítanak. A kutatás eredményei szerint az aktív pihenés és a sportolási lehetőségek önállóan is megállják a helyüket. A gasztronómia és a kulturális látnivalók, programok inkább az utazási élményt gazdagítják. A megkérdezettek szerint az egészségturisztikai szolgáltatások az utazás alatt végzett tevékenységként is csak szűk célcsoportok számára vonzóak. A víztől független vonzerők nagyobb szerepet kaptak a hazai vízpartok nemzetközi összehasonlításban megfogalmazott egyedi jellemzői között.

Területi szempontból elmondható, hogy a vizsgált belföldi potenciális utazók a magyarországi célállomásokról kisebb földrajzi egységben (tó, település) gondolkodnak, míg a külföldi desztinációk tekintetében országok jelennek meg a megkérdezettek képzeletbeli térképén.

A kutatás eredményei rávilágítottak arra, hogy a hazai vízpartok keresletének döntő hányadát adó belföldi vendégek számára az országhatáron belüli utazás számos előnnyel jár, ami független a vízparttól. A belföldi utazás mellett szóló érvek a vízparti utazásról általában kialakult imázsban nem jelentek meg, ámde szerves részét képezik a magyarországi célállomások jellemzőinek, a döntéshozatal során fontos tényezőknek és a hazai úti célok megkülönböztető jegyeinek.

A kutatás eredményei alapján összefoglalóan elmondható, hogy a magyarországi vízparti desztinációknak - konkrét úti céltól függetlenül - a természeti környezet, vagyis a víz által determinált táj komoly hivószava a potenciális utazók számára. Erre a poten- 
ciális kereslet tudatában élo" szervezőeröre épitve kapcsolódhatnak be új célállomások a turizmusba, de a fejlett turizmussal rendelkezö területek is ennek figyelembevételével léphetnek a fenntartható és versenyképes jövő útjára (3. ábra).

3. ábra: A táji környezet szerepe a vízparti utazásban

Role of the natural enviroment in waterside holiday

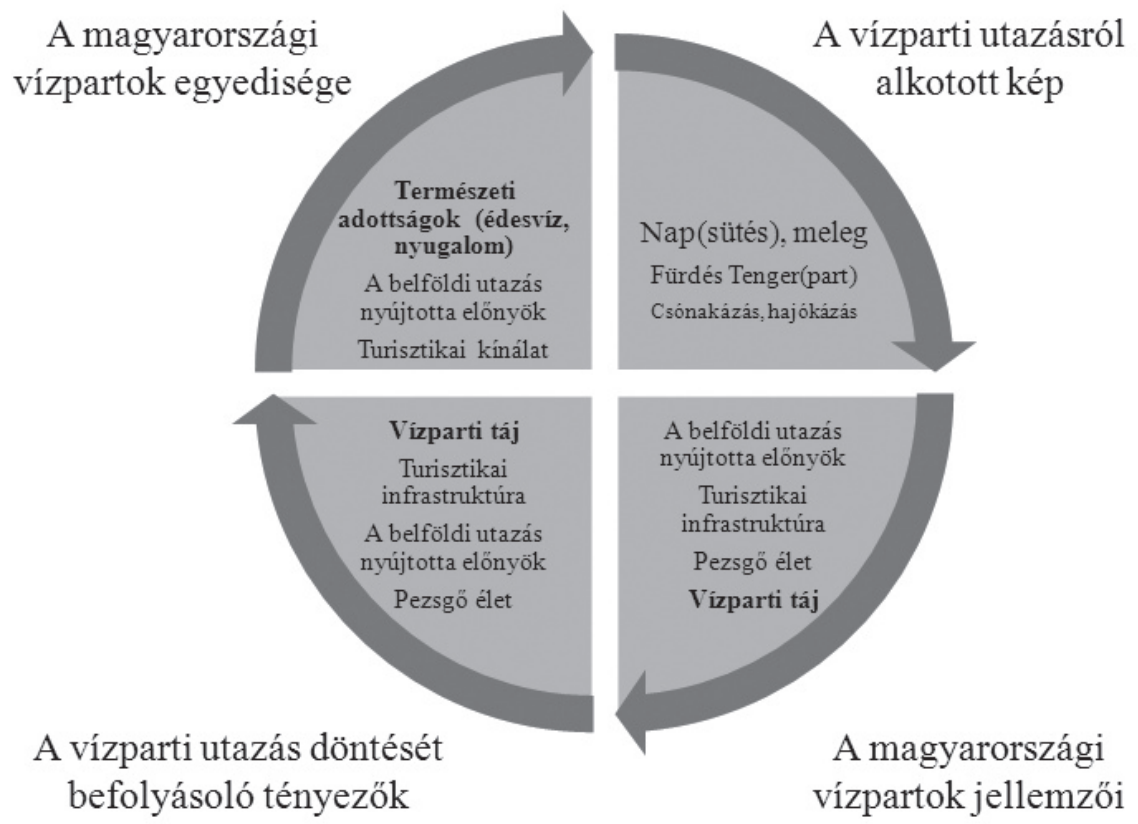

Forrás: saját kutatás.

\section{Jegyzetek}

1 Számokra lefordítva ez a kereslet 2010-ben (KSH) 16,37 millió utazási napot jelentett a „magyar tenger" számára.

2 A hazai környezethez illeszkedően, a magyar lakosság utazási szokásait vizsgáló kutatásokban a nemzetközi felmérésekben ismert „4S”, „sun\&beach” stb. megfogalmazások helyett a passzív pihenés tekinthető relevánsnak.

3 A jelen tanulmányban bemutatott elsődleges kutatás része a doktori kutatásomnak, amelynek során a lakossági megkérdezés mellett a turisztikai döntéshozók körében végzett felmérés és a média által közvetített kép elemzése vizsgálja a vízparti táji környezet szerepét az utazások során.

4 A kutatás magában foglalta továbbá a Balaton és a Tisza-tó jellemzését, a gyógyfürdővel/wellness-szállóval rendelkező magyarországi települések ismertségét és látogatottságát, valamint az ezen utazásokat befolyásoló tényezőket. Ennek eredményeit jelen tanulmányban nem ismertetem. 
5 Összehasonlításképp: 2006. január és 2009. március között a lakosság 57,3\%-a vett részt vízparti utazáson (Magyar Turizmus Zrt. 2009/a).

6 Összehasonlításképp: a magyar lakosság 90,1\%-a legalább egy alkalommal járt a Balatonnál (Magyar Turizmus Zrt. 2009/a).

7 A turisztikai szempontból szintén jelentős Fertő tavat alacsony számban említették, így külön nem vizsgálható, a további magyarországi úti célokkal együtt egy kategória foglalja magában. A tömegturizmust ez esetben pozitívumként értékelték a megkérdezettek, ez számukra egy mozgalmasabb, élettel teli célállomást jelent.

9 A kultúra és a gasztronómia inkább az utazás során végzett tevékenységekhez sorolható a válaszok alapján, önállóan az egészségturizmus és a borturizmus a legvonzóbbak. A Magyar Turizmus Zrt. balatoni marketingtevékenységében mint turisztikai termék a vízi sportok sora, a kerékpározás, a természetjárás, a lovaglás, a falusi turizmus, a gyógy- és wellness-szolgáltatás kap kiemelt hangsúlyt (Dani, G. Zsoldos 2009).

Szeretnék kösznetet mondani dr. Rátz Tamarának, a Kodolányi János Főiskola Turizmus Tanszék vezetőjének és dr. Michalkó Gábornak, az MTA CSFK Földrajztudományi Intézet tudományos tanácsadójának, hogy a kutatásban való részvételemet lehetővé tették. Ezúton szeretném továbbá megköszönni az anonim lektoroknak értékes észrevételeiket és javaslataikat.

\section{Irodalom}

Agarwal, S. (1997): The resort cycle and seaside tourism: an assessment of its applicability and validity. Tourism Management, 2., 65-73.

Baros, Z. et al. (2007): Lake tourism in light of the global climate change. In: Németh, Á., Dávid, L. (eds.): Handbook of Lakes and Reservoirs - a Sustainable Vision of Tourism. Károly Róbert Főiskola, Gyöngyös, 1-18.

Bonaiuto, M. et al. (2002): Local identity processes and environmental attitudes in land use changes: The case of natural protected areas. Journal of Economic Psychology, 23., 631-653.

Dani B., Gellénné Zsoldos N. (2010): A Balaton turisztikai régió marketingkommunikációja - A régiós üzenet és imázs, Turizmus Bulletin, 1-2., 14-17.

Dávid L., Kóródi M., Puczkó L., Vasvári M. (2010): A Tisza-tó imázsa és márkázottsága. Turizmus Bulletin, 1-2., 85-92.

Dávid L., Tóth G. (2009): Hegyvidéki területek szezonalitásának problémái a Mátravidék példáján. Földrajzi Közlemények, 133., 33-41.

Denstadli, J. M. et al. (2011): Tourist Perceptions of Summer Weather in Scandinavia. Annals of Tourism Research, 3., 920-940.

Dinya, A. (2007): Case study: The possibilities of tourism at Lake Vég in Ecséd. In: Németh, Á., Dávid, L. (eds): Handbook of Lakes and Reservoirs - a Sustainable Vision of Tourism. Károly Róbert Főiskola, Gyöngyös, 42-45.

Eco, U. (2005): A szépség története. Európa Könyvkiadó, Budapest

Farkas J. (2003): A társadalmi tér fogalma és mérési lehetőségei. Társadalomkutatás, 1., 7-32.

Galgóczy-Németh, A. (2007): Lakes as natural and artificial conditions in North-Hungary. In: Németh Á., Dávid, L. (eds.): Handbook of Lakes and Reservoirs - a Sustainable Vision of Tourism. Károly Róbert Főiskola, Gyöngyös, 56-64.

Garay, L., Canoves, G. (2011): Life Cycles, Stages and Tourism History - The Catalonia (Spain) Experience. Annals of Tourism Research, 2., 651-671.

Központi Statisztikai Hivatal (2011): Jelentés a turizmus 2010. évi teljesítményéröl. www.ksh.hu Letöltés ideje: 2011. november 28.

Kulcsár L. (2012): Vidékfejlesztés: tájjal, vagy táj nélkül? Az V. Magyar Tájökológiai Konferencián (Sopron, 2012. augusztus 30. - szeptember 1.) elhangzott előadás 
Lengyel M. (1994): A turizmus általános elmélete. KIT Képzőművészeti Kiadó, Budapest

Magyar Turizmus Zrt. (2010): A magyar lakosság utazási szokásai. http://itthon.hu/szakmaioldalak/belfoldi-turizmus/belfoldi-turizmus Letöltés ideje: 2012. január 25.

Magyar Turizmus Zrt. (2009/a): A Balaton imázsa a magyar lakosság körében, trendek és változások. Turizmus Bulletin 1-2., 2-13. Összeállította: Sulyok J.

Magyar Turizmus Zrt. (2009/b): A Tisza-tó vonzereje, azonosító jegyei, egyedisége. Turizmus Bulletin, 1-2., 77-84. oldal. Összeállította: Polgár J.

Michalkó G. (2010): Turizmológia. Akadémiai Kiadó, Budapest

Michalkó G. (2007): A turizmuselmélet alapjai. Kodolányi János Főiskola, Székesfehérvár

Michalkó G. és tsai (2007): Az új turisták feltételezett niche-jeinek területi különbségei Magyarországon. Földrajzi Értesitö, 3-4., 271-289.

Michalkó G. (2005): Turizmusföldrajz és humánökológia. Kodolányi János Főiskola - MTA Földrajztudományi Kutatóintézet, Budapest - Székesfehérvár

Moilanen, T., Rainisto, S. (2009): How to Brand Nations, Cities and Destinations - A Planning Book for Place Branding. Palgrave Macmillan, Great Britain

Molnár, Cs. (2007): Health-tourism: a new trend by the largest lakes of Hungary. In: Németh, Á., Dávid, L. (eds.): Handbook of Lakes and Reservoirs - a Sustainable Vision of Tourism. Károly Róbert Főiskola, Gyyöngyös, 96-105.

Nők a Balatonért Egyesület (2002): A Balaton könyve. Prospektus Nyomda, Veszprém

OECD: OECD Tourism Trends and Policies 2010. www.oecd.org Letöltés ideje: 2010. január 29.

Povilanskas, R., Armaitiene, A. (2011): Seaside Resort-Hinterland Nexus: Palanga, Lithuania. Annals of Tourism Research, 3., 1156-1177.

Rátz T., Michalkó G. (2008): A Balaton turisztikai miliője: a magyar tenger sajátos atmoszférájának turizmusorientált vizsgálata. Turizmus Bulletin, 4., 13-19.

Rátz, T. (2007): The adaptation and assessment of the destination lifecycle model in the Lake Balaton region, Hungary. In: Németh Á., Dávid L. (eds.): Handbook of Lakes and Reservoirs - a Sustainable Vision of Tourism. Károly Róbert Főiskola, Gyöngyös, 106-115.

Rátz T. (2006): Az éghajlati és időjárási tényezők szerepe az utazási magatartás befolyásolásában. Turizmus Bulletin, Különszám, 42-53.

Tuohino, A., Kangas, H. (2007): Lake as a resource of well-being tourism development in Eastern Finland. In: Németh, Á., Dávid, L. (eds.): Handbook of Lakes and Reservoirs - a Sustainable Vision of Tourism. Károly Róbert Főiskola, Gyöngyös, 131-141.

UNWTO: Tourism Highlights 2011 Edition. www.unwto.org Letöltés ideje: 2012. január 25.

Zalatan, A. (1996): The determinants of planning time in vacation travel. Tourism Management, 2., $123-131$.

Yeoman, I. (2007): World Tourism and the Tourist in 2030. www.tomorrowstourist.com Letöltés ideje: 2012. január 28. 